\title{
Minat Berwirausaha Mahasiswa Ditinjau Dari Self Efficacy dan Adversity Quotient
}

\author{
Rita Ningsih $^{1}$, Arfatin Nurrahmah ${ }^{2}$ \\ ${ }^{1}$ Prodi Pendidikan Matematika Universitas Indraprasta PGRI Jakarta \\ email: ritaningsih.unindra@gmail.com \\ ${ }^{1}$ Prodi Pendidikan Matematika Universitas Indraprasta PGRI Jakarta \\ email: arfatinnurrahmah@gmail.com
}

Received: 10 Juli, 2020; Accepted: 04 Desember 2020; Published: 15 Desember, 2020

\begin{abstract}
Abstrak
Tujuan dari penelitian ini adalah untuk mengetahui pengaruh secara bersama sama antara self efficacy dan adversity quotient terhadap minat berwirausaha mahasiswa, pengaruh self efficacy terhadap minat berwirausaha mahasiswa, dan pengaruh adversity quotient terhadap minat berwirausaha mahasiswa. Metode yang digunakan adalah survey. Sampel diperoleh dengan menggunakan teknik simple random sampling sebanyak 105 mahasiswa yang mengambil mata kuliah kewirausahaan pada salah satu PTS di Jakarta. Analisis data dilakukan dengan menggunakan bantuan program SPSS-16. Uji persyaratan analisis yang digunakan adalah uji normalitas, uji linearitas dan uji multikolinearitas. Uji hipotesis dengan menggunakan uji korelasional dilanjutkan dengan uji regresi ganda. Berdasarkan hasil penelitian, didapatkan hasil bahwa: 1) terdapat pengaruh self efficacy dan adversity quotient secara bersama-sama terhadap minat berwirausaha. Besar sumbangan self efficacy dan adversity quotient terhadap minat berwirausaha sebesar $45,7 \%$ sisanya sebesar 54,3\% disumbang oleh variabel-variabel lain selain self efficacy dan adversity quotient; 2) Terdapat pengaruh self efficacy terhadap minat berwirausaha, dan 3) Terdapat pengaruh adversity quotient terhadap minat berwirausaha.
\end{abstract}

Kata kunci: Adversity Quotient; Minat berwirausaha; Self Efficacy;

\begin{abstract}
The purpose of this research is to know the influence between self efficacy and adversity quotient on entrepreneurial interests of students, the effect of self efficacy on student entrepreneurial interests, and the effect of adversity quotient on student entrepreneurial interests. The method used is survey. Samples were obtained using simple random sampling technique as many as 105 students took entrepreneurship courses at one of the PTS in Jakarta. Data analysis is done using the help of the SPSS-16 program. Test requirements the analysis used is the test of normality, linearity test and multicolinearity test. The hypothesis test using a correlational test is followed by a double regression test. Based on the results of the research, the results that: 1) there are influence of self efficacy and adversity quotient jointly towards
\end{abstract}


entrepreneurial interest. Self efficacy and adversity quotient contributions to entrepreneurial interest of $45.7 \%$ of the remaining $54.3 \%$ are donated by variables other than self efficacy and adversity quotient; 2) there is self efficacy influence on entrepreneurial interest, and 3) there is adversity quotient influence on entrepreneurial interest.

Keywords: Adversity Quotient; Entrepreneurial interest; Self Efficacy;

\section{PENDAHULUAN}

Pendidikan bertujuan untuk mempersiapkan sumber daya manusia yang unggul. Pendidikan secara otomatis dapat menumbuhkembangkan potensi yang ada pada diri seseorang sehingga mewujudkan sumber daya yang memiliki daya juang tinggi. Sehingga dapat dikatakan bahwa pendidikan memiliki peran yang sangat penting untuk menghasilkan sumber daya yang berkualitas serta mampu bersaing dan berkompetisi di era globalisasi. Jenjang pendidikan terutama di pendidikan tinggi harus mampu mempersiapkan mahasiswanya menjadi anggota masyarakat yang mampu mengembangkan kemampuannya terutama di dunia kerja. Dalam meningkatkan kualitas pendidikan diperlukan perbaikan pembelajaran yang mampu mendorong pembentukan kompetensi mahasiswa di perguruan tinggi, terutama peningkatan kualitas pembelajaran pada program studi pendidikan matematika di instansi tempat peneliti mengajar.

Wirausaha menjadi salah satu pilihan dalam karir selain menjadi Pegawai Negeri Sipil (PNS), sehingga pendidikan kewirausahaan juga dapat meningkatkan minat para mahasiswa untuk memilih wirausaha sebagai salah satu pilihan favorit dalam berkarir. Pendidikan kewirausahaan dapat mengarahkan sikap, perilaku, minat dan motivasi serta pola pikir mahasiswa menjadi seorang entrepreneur sejati. Mahasiswa merupakan calon lulusan terdidik (intelektual) yang perlu didorong dan ditumbuhkan niat serta motivasi untuk berwirausaha (entrepreneurial intension) mengingat persaingan dunia bisnis saat ini dan masa mendatang lebih mengandalkan pengetahuan (knowledge) (Ningsih, 2017).

Minat tidak dibawa sejak lahir tetapi minat tumbuh dan berkembang sesuai dengan faktor-faktor yang mempengaruhinya. Minat yang besar terhadap sesuatu ini merupakan modal yang besar untuk mencapai tujuan yang diinginkan JPEK, Vol. 4, No. 2 Desember 2020. • 162 
(Nurrahmah, 2015). Minat berwirausaha adalah ketertarikan serta kesediaan untuk bekerja keras tanpa takut menanggung resiko kegagalan, serta senantiasa belajar dari kegagalan yang dialami sehingga mampuefi mengoptimalkan segala sumber daya untuk menghasilkan suatu produk atau usaha yang berguna sehingga mencapai kesuksesan yang diinginkan.

Perasaan senang merupakan kesenangan atau kesukaan untuk melakukan suatu tindakan sehingga cenderung akan melakukan pendekatan terhadap kegiatan yang digelutinya. Seseorang yang memiliki ketertarikan untuk berwirausaha akan merasa mampu untuk mengatasi segala resiko yang akan dihadapi, karena mereka menyadari bahwa untuk menjadi seorang wirausahan yang sukses, mereka harus mampu menghadapi segala resiko. Perhatian adalah konsentrasi atau aktifitas jiwa pada kemungkinan hasil yang didapatkan akan baik dan sesuai yang diharapkan. Perhatian ini perlu menjadi indikator suatu minat berwirausaha karena jika seseorang sudah berminat pada sesuatu, maka akan berharap untuk mendapatkan hasil baik dari apa yang sudah diusahakannya. Sehingga dalam penelitian ini, indikator minat berwirausaha yang digunakan adalah perasaan senang, ketertarikan, perhatian dan keterlibatan (Shoimah, 2019).

Terdapat beberapa faktor yang mempengaruhi tinggi rendahnya minat berwirausaha pada mahasiswa diantaranya faktor ektsternal dan internal. Faktor eksternal berasal dari luar diri individu, antara lain lingkungan keluarga maupun lingkungan sekitar. Sedangkan faktor internal berasal dari dalam diri individu itu sendiri, antara lain kepribadian, efikasi diri (self efficacy), kecerdasan adversity (adversity quotient) maupun motif berwirausaha. Dari berbagai macam faktorfaktor tersebut, beberapa dapat diukur secara lansgung, beberapa tidak dapat diukur secara langsung. Pada penelitian ini, akan dibatasi mengenai faktor internal yang dianggap memiliki pengaruh terhadap minat berwirausaha mahasiswa, yaitu self efficacy dan adversity quotient.

Self-Efficacy adalah sebuah keyakinan subjektif individu untuk mampu mengatasi permasalahan-permasalan atau tugas, serta melalukan tindakan yang diperlukan untuk mencapai tujuan yang diinginkan (Riwayati \& Gunadi, 2015). Ketika berhadapan dengan suatu kondisi, dalam diri individu dapat muncul rasa dan JPEK, Vol. 4, No. 2 Desember 2020. • 163 
keyakinan bahwa dirinya mampu/tidak mampu mengatasi kondisi tersebut. Keyakinan akan kemampuan diri inilah yang dikaitkan dengan istilah self-efficacy (Lianto, 2019).

Adapun indikator dari self efficacy (efikasi diri) menurut Bandura, antara lain: a) Tingkat (level). Tingkat yang dimaksudkan adalah tingkatan kesulitan yang mampu dilakukan mahasiswa dari tugas yang diberikan; b) Kekuatan (strength). Kekuatan yang dimaksudkan adalah keyakinan atau pengharapan mahasiswa mengenai kemampuannya; c) Generalisasi (generality). Generalisasi yang dimaksudkan adalah keyakinan mahasiswa akan kemampuan terhadap dirinya sendiri (Fradani, 2017).

Selain self efficacy, faktor lain yang dianggap berpengaruh terhadap minat berwirausaha mahasiswa yaitu adversity quotient. Tanpa adanya adversity quotient (AQ) yang tinggi, maka dikhwatirkan seseorang akan mengalami frustasi dan kegamangan dalam menjalani proses menjadi seorang wirausahawan (Astri \& Latifah, 2017). Menurut Stoltz, adversity quotient dibagi menjadi empat skor berdasarkan dimensi CORE, antara lain: a) C adalah Control (kendali). Kontrol adalah seberapa besar kendali serta kemampuan seseorang dalam mempengaruhi situasi yang ada, kemudai mengubah situasi yang sulit tersebut dan menjadi pribadi yang tidak mudah menyerah; b) $\mathrm{O}$ adalah Ownership adalah sejauh mana seseorang memeiliki rasa tanggung jawab untuk memperbaiki situasi sulit yang sedang dihadapi; c) R adalah Reach (jangkauan) adalah seberapa jauh kesulitan atau permasalahan yang dihadapi seseorang berpengaruh pada aspek-aspek kehidupan lainnya; d) E adalah Endurance (daya tahan) adalah seberapa besar daya tahan ketika sedang menghadapi suatu permasalahan (Palupi, 2015).

Oleh karena itu, peneliti perlu menguji pengaruh self efficacy dan adversity quotient terhadap minat berwirausaha mahasiswa, terutama mahasiswa di lingkungan program studi pendidikan matematika di salah satu PTS di Jakarta, berdasarkan latar belakang tersebut, maka tujuan penelitian ini adalah mengetahui : 1) Pengaruh secara bersama sama antara self efficacy dan adversity quotient terhadap minat berwirausaha mahasiswa; 2) Pengaruh self efficacy terhadap minat 
berwirausaha mahasiswa; dan 3) Pengaruh adversity quotient terhadap minat berwirausaha mahasiswa.

\section{METODE}

Penelitian dilakukan pada salah satu kampus di Jakarta Timur. Penelitian dilakukan selama lima bulan mulai bulan Maret hingga Juli 2020. Penelitian dilakukan pada semester genap tahun akademik 2019/2020 pada salah satu PTS di Jakarta Timur. Pendekatan yang digunakan dalam penelitian ini adalah pendekatan kuantitatif. Penelitian kuantitatif adalah suatu metode penelitian dimana data penelitian berupa angka-angka dan analisis menggunakan statistik (Sugiyono, 2013). Variabel pada penelitian ini yaitu minat berwirausaha (Y), serta self efficacy $\left(\mathrm{X}_{1}\right)$, dan adversity quotient $\left(\mathrm{X}_{2}\right)$. Adapun desain untuk menggambarkan hubungan dalam penelitian ini, dapat dilihat pada gambar berikut.

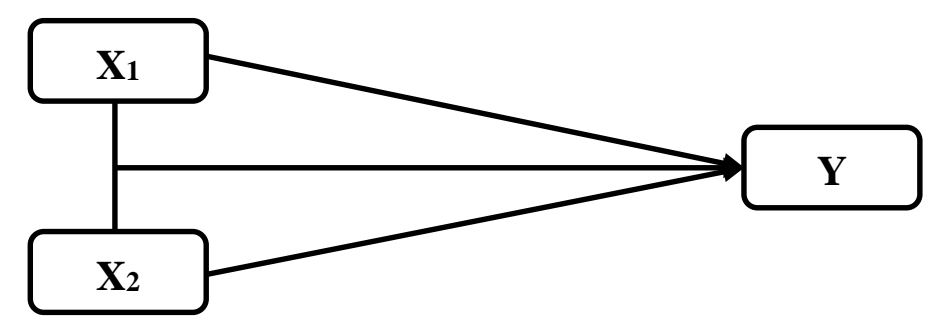

Gambar. 1 Desain Penelitian

Populasi yang digunakan dalam penelitian ini adalah seluruh mahasiswa semester 8 yang mengambil mata kuliah aplikasi kewirausahaan di semester genap tahun akademik 2019/2020 dengan jumlah sekitar 150 Mahasiswa. Dalam penentuan sampel menggunakan teknik simple random sampling dimana tiap mahasiswa karakteristik populasi memiliki peluang yang sama untuk dijadikan sampel sesuai dengan jumlah populasi. Berdasarkan jumlah populasi, maka sampel yang diambil dapat dihitung sesuai dengan pendapat Isaac dan Michael dengan taraf kesalahan 5\%, sebanyak 105 sampel. Teknik analisis data yang digunakan untuk menjawab tujuan penelitian adalah analisis regresi ganda untuk menguji pengaruh antara variabel bebas (self efficacy dan adversity quotient) terhadap variabel terikat (minat berwirausaha). Sebelumnya akan dilakukan uji prasyarat analisis data antara lain, uji normalitas, uji linearitas dan uji multikolinearitas. 


\section{HASIL PENELITIAN DAN PEMBAHASAN}

\section{Hasil}

Data yang dideskripsikan merupakan data dari responden mengenai skor self efficacy, adversity quotient, dan minat berwirausaha mahasiswa. Ketiga data yang dideskripsikan, self efficacy, adversity quotient, dan minat berwirausaha mahasiswa didapatkan melalui kuesioner yang disusun peneliti berdasarkan indikator-indikatornya. Deskripsi data dari ketiga variabel tersebut dengan menggunakan SPSS-16 sebagai berikut:

Tabel : 1

Deskripsi Data Penelitian

\begin{tabular}{llrrr}
\hline & & \multicolumn{1}{c}{$\mathbf{X}_{\mathbf{1}}$} & $\mathbf{X}_{\mathbf{2}}$ & \multicolumn{1}{c}{$\mathbf{Y}$} \\
\hline $\mathrm{N}$ & Valid & 105 & 105 & 105 \\
\cline { 2 - 5 } & Missing & 15 & 15 & 15 \\
\hline Mean & 31,80 & 27,50 & 34,85 \\
\hline Median & 32,00 & 27,00 & 34,00 \\
\hline Mode & 30 & 27 & 32 \\
\hline Std. Deviation & 3,182 & 3,058 & 3,319 \\
\hline Range & 16 & 16 & 22 \\
\hline Minimum & 22 & 20 & 20 \\
\hline Maximum & 38 & 36 & 42 \\
\hline Sum & 3339 & 2887 & 3659 \\
\hline
\end{tabular}

Sumber: Data Penelitian

Berdasarkan data penelitian yang tertera pada tabel 1, untuk self efficacy diperoleh skor minimum 22 dan skor maksimum 38. Secara keseluruhan skor self efficacy adalah sebagai berikut: rata - rata: 31,80; median: 32; modus: 30 , dan angka simpangan baku sebesar 3,182 atau sama dengan $10 \%$ dari rata-rata, menunjukkan perbedaan self efficacy antar responden termasuk rendah. Hal ini menunjukkan bahwa self efficacy dari responden tidak banyak beragam. Untuk adversity quotient diperoleh skor minimum 20 dan skor maksimum 36. Secara keseluruhan skor adversity quotient adalah sebagai berikut: rata - rata: 27,50; median: 27; modus: 27 , dan angka simpangan baku sebesar 3,058 atau sama 
dengan $11,12 \%$ dari rata-rata, menunjukkan perbedaan adversity quotient antar responden termasuk rendah. Hal ini menunjukkan bahwa adversity quotient dari responden tidak banyak beragam. Selajutnya, untuk minat berwirausaha diperoleh skor minimum 20 dan skor maksimum 42. Secara keseluruhan skor minat berwirausaha adalah sebagai berikut: rata-rata: 34,85; median: 34; modus: 32 , dan angka simpangan baku sebesar 3,319 atau sama dengan 9,52\% dari rata-rata, menunjukkan perbedaan minat berwirausaha antar responden termasuk rendah. Hal ini menunjukkan bahwa minat berwirausaha dari responden tidak banyak beragam. Selanjutnya diadakan uji persyaratan data, yaitu uji normalitas, uji linearitas, dan uji multikolinearitas.

Uji normalitas dilakukan untuk mengetahui apakah data yang diperoleh peneliti berasal dari populasi berdistribusi normal atau tidak. Dalam melakukan uji normalitas, peneliti menggunakan SPSS 16 sebagai alat bantu. Dalam hal ini peneliti menggunakan Uji Kormogorov-Smirnov. Pengujian normalitas data masing-masing sampel diuji melalui hipotesis:

$\mathrm{H}_{0}$ : data berasal dari populasi yang berdistribusi normal

$\mathrm{H}_{1}$ : data berasal dari populasi yang tidak berdistribusi normal

Dalam hal ini yang diuji adalah Hipotesis nol $\left(\mathrm{H}_{0}\right)$, yaitu "sampel berasal dari distribusi normal", kemudian dibandingkan dengan Sig dengan taraf signifikansi pada $\alpha=0,05$. Dengan kriteria pengujian, jika $\operatorname{Sig}>0,05$, maka $\mathrm{H}_{0}$ diterima, yang artinya sampel berasal dari populasi yang distribusi normal. Berdasarkan hasil perhitungan uji normalitas dengan berbantuan SPSS-16, diperoleh hasil sebagai berikut:

Tabel : 2

Hasil Pengujian Normalitas

\begin{tabular}{ccc}
\hline Variabel & $P$ & Simpulan \\
\hline $\mathrm{X}_{1}$ & 0,200 & Data Berdistribusi Normal \\
\hline $\mathrm{X}_{2}$ & 0,096 & Data Berdistribusi Normal \\
\hline $\mathrm{Y}$ & 0,077 & Data Berdistribusi Normal
\end{tabular}

Sumber : Data Penelitian 
Dari tabel 2 di atas terlihat bahwa nilai pada kolom Sig untuk semua sampel lebih dari 0,05 , sehingga $\mathrm{H}_{0}$ diterima, yang artinya bahwa dari semua data sampel pada penelitian ini berdistribusi normal, sehingga dapat dilanjutkan ke tahapan pengujian hipotesis. Selanjutnya dilakukan uji linearitas untuk mengetahui, membuktikan bahwa hunbungan antar variabel yang diteliti memiliki hubungan yang linear. Dalam melakukan uji linear, peneliti melakukan analisis regresi dengan bantuan SPSS-16 dengan kriteria:

$$
\begin{aligned}
& \mathrm{H}_{0}: \hat{Y}=a+b X \\
& \mathrm{H}_{1}: \hat{Y} \neq a+b X
\end{aligned}
$$

Kriteria pengujiannya adalah jika $\mathrm{Sig}>0,05$, maka $\mathrm{H}_{0}$ diterima artinya adalah persamaan regresi berbentuk linear. Hasil pengujian linearitas untuk kedua model regresi sederhana dapat dilihat pada tabel berikut ini:

Tabel : 3

Hasil Uji Linearitas

\begin{tabular}{ccc}
\hline Garis yang diuji & $P$ & Simpulan \\
\hline $\mathrm{X}_{1}$ terhadap Y & 0,060 & model regresi berpola linear \\
\hline $\mathrm{X}_{2}$ terhadap Y & 0,358 & model regresi berpola linear \\
\hline
\end{tabular}

Sumber: Data Penelitian

Berdasarkan tabel 3, diperoleh nilai Sig ( $P$-value $)$ untuk kedua model regresi di atas $>0,05$. Hal ini menunjukkan bahwa kedua model regresi sederhana yang terbentuk berpola linear, sehingga dapat dilanjutkan ke pengujian hipotesis. Selanjutnya dilakukan uji multikolinearitas. Uji multikolinearitas bertujuan untuk menguji apakah model regresi ditemukan adanya korelasi yang sempurna antara variabel bebas (independent). Model regresi yang baik seharusnya tidak terjadi korelasi yang sempurna diantara variabel bebas. Salah satu cara untuk mendeteksi adanya multikolinearitas adalah dengan melihat tolerance atau Varians Inflation Factor (VIF). Hipotesis yang digunakan:

$$
\begin{aligned}
& \mathrm{H}_{0} \text { : Terjadi multikolinearitas } \\
& \mathrm{H}_{1} \text { : Tidak terjadi multikolinearitas }
\end{aligned}
$$


Kriteria pengujian multikolinearitas adalah: Jika nilai Tolerance $\leq 0,1$ atau nilai VIF $\geq 10$, maka terjadi multikolinearitas. Dengan menggunakan SPSS 16 diperoleh hasil pengujian multikolinearitas sebagai berikut:

Tabel : 4

Uji Multikolinearitas

\begin{tabular}{ccc}
\hline Variabel Bebas & \multicolumn{2}{c}{ Collinearity Statistic } \\
\cline { 2 - 3 } & Tolerence & VIF \\
\hline Self Efficacy & 0,532 & 1,881 \\
\hline Adversity Quotient & 0,532 & 1,881 \\
\hline Sumber: Data & &
\end{tabular}

Sumber: Data Penelitian

Berdasarkan hasil pengujian pada tabel 4 di atas, diperoleh nilai Tolerance $0,532>0,1$ dan $\mathrm{VIF}=1,881<10$. Sehingga dapat dinyatakab bahwa tidak terjadi multikolinearitas antara Self Efficacy dan Adversity Quotient. Sesudah uji persyaratan analisis sudah terpenuhi, maka dapat dilanjutkan dengan uji hipotesis penelitian. Pengujian hipotesis dan analisis data dilakukan dengan bantuan program SPSS- 16. Hasil pengujian hipotesis dapat dilihat pada tabel berikut:

Tabel : 5

Uji Korelasi Ganda

\begin{tabular}{lrrrr} 
Model & $R$ & $R$ Square & Adjusted $R$ Square & \multicolumn{2}{c}{$\begin{array}{c}\text { Std. Error of the } \\
\text { Estimate }\end{array}$} \\
\hline 1 & $0,676^{\mathrm{a}}$ & 0,457 & 0,447 & 2,468 \\
\hline
\end{tabular}

a. Predictors: (Constant), Adversity_Quotient, Self_Efficacy

b. Dependent Variabel : Minat Berwirausaha

Berdasarkan tabel 5, diperoleh nilai $\mathrm{R}=0,676$ yang menujukkan terdapat korelasi positif yang cukup kuat antara self efficacy dan adversity quotient dengan minat berwirausaha mahasiswa. Hal ini didukung dengan nilai $\mathrm{R}$ square $=0,457$ atau koefisien determinasinya 45,7\%. Artinya minat berwirausaha mahasiswa dipengaruhi oleh faktor self efficacy dan adversity quotient sebesar 45,7\% dan faktor lain sebesar 54,3\%. 
Tabel : 6

Uji Regresi Ganda

\begin{tabular}{|c|c|c|c|c|c|c|}
\hline Model & & Sum of Squares & $d f$ & Mean Square & $F$ & Sig. \\
\hline \multirow[t]{3}{*}{1} & Regression & 524,046 & 2 & 262,023 & 43,002 & $0,000^{\mathrm{a}}$ \\
\hline & Residual & 621,515 & 102 & 6,093 & & \\
\hline & Total & 1145,562 & 104 & & & \\
\hline
\end{tabular}

a. Predictors: (Constant), Adversity_Quotient, Self_Efficacy

b. Dependent Variable: Minat_Berwirausaha

Berdasarkan tabel 6, diperoleh nilai Sig. $=0,000$ atau Sig. $<0,05$ yang artinya terdapat pengaruh siginfikan self efficacy dan adversity quotient terhadap minat berwirausaha mahasiswa. Kemudian dilanjutkan dengan uji lanjut regresi yaitu mencari uji regresi sederhana seperti pada tabel 7 berikut:

Tabel : 7

Uji Lanjut Regresi

\begin{tabular}{|c|c|c|c|c|c|c|}
\hline & \multirow[b]{2}{*}{ Model } & \multicolumn{2}{|c|}{$\begin{array}{c}\text { Unstandardized } \\
\text { Coefficients }\end{array}$} & \multirow{2}{*}{$\begin{array}{c}\text { Standardized } \\
\text { Coefficients }\end{array}$} & \multirow[b]{2}{*}{$\mathrm{t}$} & \multirow[b]{2}{*}{ Sig. } \\
\hline & & $\mathrm{B}$ & Std. Error & & & \\
\hline \multirow[t]{3}{*}{1} & (Constant) & 12,376 & 2,534 & & 4,884 & 0,000 \\
\hline & Self_Efficacy & 0,238 & 0,104 & 0,228 & 2,278 & 0,025 \\
\hline & $\begin{array}{c}\text { Adversity_Quot } \\
\text { ient }\end{array}$ & 0,542 & 0,109 & 0,500 & 4,996 & 0,000 \\
\hline
\end{tabular}

a. Dependent Variable: Minat_Berwirausaha

Berdasarkan tabel 7, diperoleh nilai Sig. $=0,025$ untuk self efficacy dan Sig. $=0,000$ untuk adversity quotient. Kedua nilai Sig. tersebut $<0,05$. Hal ini menunjukkan bahwa secara parsial terdapat pengaruh signifikan antara self efficacy terhadap minat berwirausaha mahasiswa dan terdapat pengaruh signifikan antara adversity quotient terhadap minat berwirausaha mahasiswa.

\section{Pembahasan}

\section{Pengaruh Self Efficacy dan Adversity Quotient secara bersama-sama terhadap Minat Berwirausaha}


Berdasarkan hasil pengujian hipotesis didapatkan bahwa terdapat pengaruh Self Efficacy dan Adversity Quotient secara bersama-sama terhadap Minat Berwirausaha. Untuk Self Efficacy, nilai thitung $=2,278$ dan Sig. $<0,05$; untuk Adversity Quotient nilai $t_{\text {hitung }}=4,996$ dan Sig. $<0,05$. Diperoleh pula persamaan regresi ganda $\mathrm{Y}=12,376+0,238 \mathrm{X}_{1}+0,542 \mathrm{X}_{2}$. Berdasarkan persamaan tersebut, menunjukkan bahwa setiap kenaikan satu unit Self Efficacy dan setiap kenaikan satu unit Adversity Quotient secara berasama-sama akan meningkatkan minat berwirausaha mahasiswa sebesar 0,78 unit $\left(=0,238 X_{1}+0,542\right)$ secara siginifikan $P$-value (Sig. $)=0,00$.

Nilai koefisien determinasi digunakan untuk menentukan besar sumbangan (kontribusi) variabel self efficacy $\left(X_{1}\right)$ dan variabel $\left(X_{2}\right)$ terhadap minat berwirausaha mahasiswa (Y). Hasil pengolahan data dari program SPSS-16 diperoleh $\mathrm{R}$ square $=0,457$, sehingga besar nilai koefisien determinasinya sama dengan $0,457 \times 100 \%=45,7 \%$. Selanjutnya, dari tabel ANOVA, diperoleh nilai $F_{\text {hitung }}=43,002$ dengan nilai Sig $=0,000$ lebih kecil dari 0,05. Hal ini berarti terdapat sumbangan signifikan antara self efficacy dan adversity quotient terhadap minat berwirausaha mahasiswa secara bersama-sama yang besarnya 45,7\% sedang sisanya 54,3\% disumbangkan oleh variabel lain selain self efficacy dan adversity quotient.

Pendapat ini juga mendukung hasil penelitian yang dilakukan oleh Frandani (2014) bahwa jika seseorang memiliki kecerdasan adversitas dan efikasi diri yang tinggi maka minat berwirausaha juga akan menjadi tinggi. Hasil ini menunjukan bahwa sikap positif akan wirausaha akan diterjemahkan menjadi niat atau minat wirausaha, sebaliknya jika muncul sikap negatif juga otomatis menurunkan niat untuk berwirausaha.

Hal ini juga menunjukkan bahwa mahasiswa memiliki pemikiran bahwa berwirausaha memiliki manfaat bagi kehidupannya di masa yang akan datang. Dengan adanya respon positif terhadap minat berwirausaha diharapkan menjadi stimulus bagi terbentuknya wirausaha-wirausaha muda baru dikalangan mahasiswa (Palupi, 2015). Sehingga dari uraian tersebut, dapat disimpulkan bahwa terdapat pengaruh self efficacy dan adversity quotient terhadap minat JPEK, Vol. 4, No. 2 Desember 2020. • 171 
berwirasusaha, artinya kedua faktor yang mempengaruhi minat berwirausaha mahasiswa harus terus dikembangkan.

\section{Pengaruh Self Efficacy terhadap Minat Berwirausaha}

Berdasarkan hasil pengujian hipotesis, didapatkan bahwa ada pengaruh self efficacy terhadap minat berwirausaha mahasiswa. Nilai thitung $=2,278$ dan Sig. $<$ 0,05 ; dengan persamaan linear $\mathrm{Y}=12,376+0,238 \mathrm{X}_{1}$. Hal ini menunjukkan bahwa setiap kenaikan satu unit self efficacy akan meningkatkan minat berwirausaha mahasiswa sebesar 0,238 unit secara signifikan, ceteris paribus atau variabel adversity quotient tidak berubah.

Selanjutnya, berdasarkan hasil perhitungan statistik dan uji hipotesis untuk self efficacys telah diaparkan bahwa terdapat pengaruh positif yang siginfikan self efficacy terhadap minat berwirausaha mahasiswa. Self efficacy memiliki peran penting dalam minat berwirausaha seorang mahasiswa, karena self efficacy sendiri dapat melukiskan perilaku yang disertai dengan kedisiplinan dan upaya melakukan tindakan yang lebih bijak serta dapat mempengaruhi kesuksesan seorang individu. Hasil penelitian ini mendukung pendapat yang menyatakan bahwa efikasi diri (self efficacy) memiliki peranan penting terhadap minat berwirausaha, semakin tinggi kepercayaan diri siswa atas kemampuan dirinya untuk dapat berusaha, maka semakin besar pula intensi berwirausahanya (Fradani, 2017).

Hal senada dengan pendapat bahwa terdapat hubungan yang positif dan signifikan antara efikasi diri terhadap minat berwirausaha pada mahasiswa. Dengan demikian semakain tinggi efikasi diri maka semakin tinggi pula minat berwirausaha pada mahasiswa, begitu jika sebaliknya, semakin rendah efikasi diri maka semakin rendah pula minat berwirausaha pada mahasiswa. Sehingga dari uraian di atas, dapat disimpulkan bahwa terdapat pengaruh self efficacy terhadap minat berwirasusaha, artinya faktor yang mempengaruhi minat berwirausaha mahasiswa harus terus dikembangkan (Nurhayati et al., 2019).

\section{Pengaruh Adversity Quotient terhadap Minat Berwirausaha}

Berdasarkan hasil pengujian hipotesis, didapatkan bahwa ada pengaruh adversity quotient terhadap minat berwirausaha mahasiswa. Nilai $t_{\text {hitung }}=4.996$ 
dan Sig. $<$ 0,05; dengan persamaan linear $\mathrm{Y}=12,376+0,542 \mathrm{X}_{2}$. Hal ini menunjukkan bahwa setiap kenaikan satu unit adversity quotient akan meningkatkan minat berwirausaha mahasiswa sebesar 0,542 unit secara signifikan, ceteris paribus atau variabel self efficacy tidak berubah.

Selanjutnya, berdasarkan hasil perhitungan statistik dan uji hipotesis untuk adversity quotient, telah diaparkan bahwa terdapat pengaruh positif yang siginfikan adversity quotient terhadap minat berwirausaha mahasiswa. Hasil penelitian ini mendukung pendapat yang menyatakan bahwa variabel komponen kontrol (kendali) dalam adversity quotient ditemukan berpengaruh positif signifikan terhadap minat berwirausaha. Seseorang dengan kendali / kontrol diri akan memiliki kemampuan untuk mempengaruhi situasi yang ada, merubah situasi yang sulit, menjadi pribadi yang tidak mudah menyerah dan memiliki kendali atas situasi yang dihadapi. Karakteristik ini berperan dalam membentuk jiwa wirausaha yang tangguh (Palupi, 2015).

\section{KESIMPULAN}

Berdasarkan hasil pengujian hipotesis dan hasil penelitian, maka didapatkan kesimpulan sebagai berikut: 1) Terdapat pengaruh self efficacy dan adversity quotient secara bersama-sama terhadap minat berwirausaha. Berdasarkan uji regresi ganda, diperoleh nilai Sig. $=0,000$ atau Sig. $<0,05$ yang artinya terdapat pengaruh siginfikan self efficacy dan adversity quotient terhadap minat berwirausaha mahasiswa. Besar sumbangan self efficacy dan adversity quotient terhadap minat berwirausaha sebesar $45,7 \%$ sisanya sebesar 54,3\% disumbang oleh variabel-variabel lain selain self efficacy dan adversity quotient; 2) Terdapat pengaruh self efficacy terhadap minat berwirausaha. Berdasarkan uji regresi sederhana, diperoleh nilai Sig. = 0, 025 untuk self efficacy Hal ini menunjukkan bahwa secara parsial terdapat pengaruh signifikan antara self efficacy terhadap minat berwirausaha mahasiswa; 3)Terdapat pengaruh adversity quotient terhadap minat berwirausaha. Berdasarkan uji regresi sederhana, diperoleh nilai Sig. $=0,000$ untuk adversity quotient. Hal ini menunjukkan bahwa secara parsial terdapat 
pengaruh signifikan antara adversity quotient terhadap minat berwirausaha mahasiswa.

\section{DAFTAR RUJUKAN}

Astri, W., \& Latifah, L. (2017). Pengaruh Personal Attributes, Adversity Quotient Dengan Mediasi Self Efficacy Terhadap Minat Berwirausaha. Economic Education Analysis Journal, 6(3), 737-751.

Fradani, A. C. (2017). Pengaruh Kecerdasan Adversitas, Pendidikan Kewirausahaan Dalam Keluarga, Dukungan Keluarga, Dan Efikasi Diri Pada Intensi Berwirausaha Siswa Smk Negeri 2 Nganjuk. Jurnal Ekonomi $\begin{array}{llll}\text { Pendidikan Dan } & 157 .\end{array}$ https://doi.org/10.26740/jepk.v2n2.p157-170

Lianto, L. (2019). Self-Efficacy: A Brief Literature Review. Jurnal Manajemen Motivasi, 15(2), 55. https://doi.org/10.29406/jmm.v15i2.1409

Ningsih, R. (2017). Peranan Pendidikan Kewirausahaan Dalam Mahasiswa. ProsidingLPPM Univ.Indraprasta PGRI, 60-69.

Nurhayati, R., Farradinna, S., \& Nugroho, S. (2019). Efikasi Diri Dan Dukungan Sosial Keluarga Memprediksi Minat Berwirausaha Pada Mahasiswa. Proyeksi: Jurnal Psikologi, 14(2), 59-70. http://lppmunissula.com/jurnal.unissula.ac.id/index.php/proyeksi/article/view/4850

Nurrahmah, A. (2015). Pengaruh Kecerdasan Logik Matematika Dan Minat. Formatif: Jurnal Ilmiah Pendidikan MIPA.

Palupi, D. (2015). Pengaruh Adversity Quotiont Dan Pendidikan Kewirausahaan Terhadap Minat Berwirausaha Mahasiswa. Pengaruh Adversity Quotiont Dan Pendidikan Kewirausahaan Terhadap Minat Berwirausaha Mahasiswa, 9(2), 128-141.

Riwayati, A., \& Gunadi, T. (2015). Pengaruh Efikasi Diri Terhadap Minat Berwirausaha Siswa Sekolah Menengah Program Keahlian Rekayasa Perangkat Teknologi Informasi Dan Komunikasi. Coopetition, 6(1), 39. http://ikopin.ac.id/jurnal/index.php/coopetition/article/view/18

Shoimah, S. (2019). Pengaruh Self Efficacy, Lingkungan Keluarga dan Pendidikan Kewirausahaan terhadap Minat Berwirausaha Mahasiswa Fakultas Ekonomi UNISDA Lamongan. 2(2), 189-203. 